\title{
SUSTAINABLE FUTURES ONLINE
}

\author{
DEREK RAINE, \\ CENTRE FOR INTERDISCIPLINARY SCIENCE, jdr@le.ac.uk, \\ SARAH GRETTON, \\ CENTRE FOR INTERDISCIPLINARY SCIENCE, sng8@le.ac.uk, \\ DUNCAN GREENHILL, \\ WEB DEVELOPER, SCHOOL OF BIOLOGICAL SCIENCES dg144@le.ac.uk \section{LITERACY} \\ KEYWORDS: SUSTAINABILITY, SUSTAINABILITY EDUCATION, SUSTAINABILITY
}

The University of Leicester's Learning and Teaching strategy (2011-15) aspired to offer all students access to the wider sustainability agenda beyond their subject specialism. Around 60\% of Leicester Students surveyed in 2012 felt that the University should provide teaching and learning about environmental and social issues. This paper reports on a project to adapt existing material from some modules on sustainability, delivered face-to-face by the Centre for Interdisciplinary Science, in order to create a non-credit bearing course in sustainability delivered on-line and available to all students (and staff) at the University. We report on some issues in the re-purposing of the material, the reception of the on-line course and its impact on efforts to embed sustainability literacy in the undergraduate curriculum.

\section{INTRODUCTION}

The University of Leicester's Learning and Teaching strategy (2011-15) aspired to offer all students access to the wider sustainability agenda beyond their subject specialism to develop "sustainability literacy". This was left undefined in the strategy, but was intended to include awareness of the political, social, economic and educational agenda around Education for Sustainable Development (ESD). Also left undefined were the means by which sustainable literacy would be achieved beyond audits, explorations of options and a reference to the ESD forum (see below). Rather, the focus of sustainability at senior management level has been on the University estate, with much attention to "greening" buildings and transport, as well as initiating links with institutions in developing countries, but rather less on academic aspects as part of the formal curriculum.

There were many isolated activities in teaching and research although, in many cases, with limited visibility, contributing to an impression of a total that was rather less than the sum of its parts. In 2005 the ESD forum was founded as an informal group of enthusiastic staff to address this issue. Various initiatives including collation of activities on a web site, regular seminars and links to regional bodies were pursued. One particular initiative in 2008 was the development of a campus-wide ESD module, called Sustainable Futures (section 2). While it was hoped that this would make a contribution to the sustainability strategy, timetabling issues meant that only a very small number of students took up the opportunity. In addition, since it was not a credit bearing module, students obtained no recognition for attendance or completion of the assignments, which may have had a bearing on the uptake.

Nevertheless, the course received a positive evaluation and, as we discuss in section 2 , there was a perceived interest amongst the student body in sustainability as part of the curriculum. One outcome has been that sustainability literacy now has to be considered in new course proposals. The object of the project described in this paper was to develop an on-line module that could be deployed across the University thereby giving students a greater opportunity to develop sustainability literacy. In 
section 2 we describe the background to the on-line course as it arose out of a campus-based module. We give some of the global context as well as the institutional one that led to the form and content of the course. In section 3 we describe the implementation of the course and its evaluation. The final sections summarise the outcomes and our conclusions. The paper will show how a bottom-up approach on a university-wide scale can influence senior management and can lead to strategic developments.

\section{BACKGROUND}

In this section we summarise the landscape of education for sustainable development (ESD) in higher education (HE), at least in as far as we were aware of it and to the extent that it impacted on the project. We discuss our starting point at the University of Leicester: first the campus course from which the on-line version was derived; then the comparison with other material available on-line.

Since the Tailores declaration of 1990 there have been numerous initiatives to promote ESD in universities (Tilbury, 2011). These range from programmes of staff development, masters programmes and individual initiatives in existing programmes (Kapitulčinová et al., 2015; Sterling et al., 2013; Holdsworth and Thomas, 2015). Despite these efforts sustainable literacy is not wellembedded in undergraduate programmes. To quote from the preface of Sterling et al.:

And yet, to be blunt, despite encouraging signs of change, sustainability remains a minority sport. Both nationally and internationally, only a small proportion of institutions are taking serious steps to push the boundaries of discovering what a fully engaged 'sustainable university' might mean.

Our ambitions were (and remain) more modest. We wanted to address the third division status of the University of Leicester in the Green League ${ }^{1}$ (a position that did not appear to be a priority for our hard-pressed senior management) at least in the area of the curriculum, and to see what could be done across the institution from a "bottom-up" approach.

Starting in 2008 as a single 5-credit module (at the time equivalent to 37.5 hours of student workload), the course has grown so that from 2010 to 2013 the University's Centre for Interdisciplinary Science ran a series of four modules under the Sustainable Futures title as options in its Natural Sciences programme. The content covered a range of interdisciplinary issues in sustainable development (Figure 1). They were delivered by experts from industry (e.g. economic and energy consultants) and academia (University of Leicester and other institutions). Although the topics were determined to some extent by the availability of contributors, it can be seen from figure 1 that we managed to cover a wide range of sustainability issues. The modules were also available as either credit-bearing or non-credit bearing options to all science students. Unfortunately, partly because of timetabling constraints, they were rarely taken up by students from other programmes, although a small number of students from Physics, Geography and Computer Science have taken the modules over the last few years. As a result of the low take-up, in 2013 the material was consolidated into just two five-credit modules.

The modules have proved popular with those students who do take them. Following the 2011/12 sessions, feedback was collected and analysed. Over $90 \%$ of students who took the course agreed or strongly agreed that

'The course has made me want to actively increase my knowledge of sustainable development'.

\footnotetext{
${ }^{1}$ http://peopleandplanet.org/university-league/2015/tables
} 
Students were also asked "To what extent and how has the course had an impact on your attitude towards sustainable development and your behaviour / lifestyle?"

There was a variety of responses to this, including, from three different students:

"I am thinking much more about the career paths within sustainability that are open to me."

"The course made me reflect on my future aspirations and helped focus my goals in working in sustainability."

"It has really broadened my view about sustainable development and encouraged [me] to deepen knowledge even more."

In 2012 the Sustainable Futures modules were short-listed in the courses category for the Environmental Association of Universities and Colleges Green Gown Awards.

In October and November 2012 the University Environment Team, the Students' Union and NUSSL (National Union of Students Services Limited) surveyed students in order to gain a baseline understanding of their sustainability attitudes, awareness, expectations and behaviours (and motivators and barriers) that would build understanding of students' demand for action, services and skills. A total of 693 students responded (from an undergraduate population of around 10,000). Almost $60 \%$ of those replying felt that the University should provide teaching and learning about environmental and social issues, with $43 \%$ feeling that it should be added to their current course and over $30 \%$ being prepared to attend non-compulsory workshops. This evidence was presented by student representatives to Learning and Teaching committees, but with little impact.

Part of the problem was (and is) the inflexibility of discipline based curricula. There seems to be hardly time in an undergraduate programme to deliver even that content we think an average student should know of a discipline. Counterintuitively perhaps, another issue is the effect of champions for ESD. This is already known in the context that courses are dropped when key enthusiasts leave an institution, but it also has the effect of suppressing wider developments on the grounds that " $X$ already does that in her module".

There already exist extensive on-line resources for ESD. There are numerous MOOCs available which students could follow; mooc list ${ }^{2}$ gives around eighty. But these either focus on very general citizenship (home insulation) or are addressed to specialists (water management) or come with a point of view (millennium goals). Although we have no evidence to support this, recommending our students to go online to study a $\mathrm{MOOC}$ from another institution does not feel sufficiently supportive to our "customer base". (On the other hand participation in a MOOC from one's own institution appears to work well, for example Sustainability, Society and You at the University of Nottingham.)

Our (revised) approach to widening access to sustainability literacy was therefore conceived as part of the informal curriculum, as a short course to be delivered asynchronously online open to university of Leicester staff and students. To recognise student commitment to a non-credit bearing module, the programme was designed to be eligible for the Higher Education Achievement Record (HEAR). Our criteria for success were that we got at least 100 students signed up and a substantial fraction completing the course (not necessarily for the HEAR) with positive responses to the level of content (which is quite intense) and presentation.

\section{PROJECT AIMS AND OBJECTIVES}

\footnotetext{
${ }^{2}$ https://www.mooc-list.com/
} 
In this section we look at some of issues in the transformation of a face-to-face course to an online one in the absence of technical support. While not aiming to achieve the production values of a fullyfledged $\mathrm{MOOC}$, we wanted to produce a self-contained course, not a repository of recorded lectures.

Each unit of the face-to-face modules exists as a self-contained unit comprising an on-line pre-session introduction, pre-session reading material, a multi-choice test and a 2 hour workshop. In addition to the test, assessment for year one students for each unit is via a short opinion piece for a broadsheet newspaper or web site and second year students are required to write a series of UK Parliament style "POSTnotes", one on each of their units.

The original intention of the project was to use the on-line pre-session introduction, pre-session reading material and multiple choice questionnaires in the on-line programme. The plan was to adapt the face-to-face workshops to an on-line asynchronous discussion forum. The on-line nature of the module also required creation and maintenance of a virtual learning environment (in our case Blackboard). The aim was that this would be available to any University of Leicester student as what is sometimes called a SPOC (short private on-line course) and the project would determine the feasibility and demand for continuing the programme.

The main component of the campus-based course was always seen by students to be the two hour workshop. The quality of the pre-session material provided by staff and the preparation by students, were, shall we say, somewhat variable. In the light of the fact that the workshop component would be absent from the on-line course, it was felt that the on-line material needed to be produced to a high standard. The pre-session material was therefore fundamentally re-purposed and expanded for on-line delivery. To provide a range of subject matter within the available resources, four topics were selected, each of which embodied material from more than one unit of the campus course. The topics were: One Earth: describing the limits to growth and planetary boundaries; Energy and Climate: looking at sustainable energy in the light of climate change; Feeding the World: looking at food security and sustainable agriculture; Are we doomed? looking at mitigation and adaptation to climate change in the light of historical parallels. In addition, an introductory unit discusses the history of sustainable development and various attempts to characterise what it entails. Figure 1 shows the mapping

The content of the first unit, One Earth, is standard, but challenges students to think about what is meant by sustainable development as a contestable concept. The consideration of energy and climate includes a challenge to students to develop an energy policy for a fictitious country called Northland. This is based on a pre-publication version of material developed for the Royal Society of Chemistry (Williams and Parker, 2012). The list of contents for the unit on food security was drafted by Charlotte Bishop, an undergraduate from the University Student Union Hungry for Change project ${ }^{3}$. This project also provided some video material. The student contribution came about following discussion at the ESD forum, which has a student representative, and provided a link between the Student Union project and the course.

These four units, together with an introductory one, comprise video material, suggested reading, a forum with questions for reflection and multi-choice questions. The on-line lectures were produced using Camtasia as picture-in-picture of the presenter over powerpoint slides, taking advantage of Camtasia's zoom and pan editing functions. The sound was recorded separately using "prosumer" level equipment to ensure high quality. The video was edited to include (optional) subtitles and a search function. The course has a VLE site with all the reading materials linked, and a course handbook which lists all the unit contents, references, learning objectives and the MCQs. Thus students can see the MCQs at any time without logging in to take the tests.

\footnotetext{
${ }^{3} \mathrm{http} / / /$ www.leicesterunion.com/hungry-for-change/home
} 


\begin{tabular}{|l|}
\hline The Complex World \\
\hline Earth Summit \\
\hline People and Planet \\
\hline $\begin{array}{l}\text { Education for Sustainable } \\
\text { Development }\end{array}$ Sustainable Energy \\
\hline $\begin{array}{l}\text { Sustainable Use of Natural } \\
\text { Resources }\end{array}$ \\
\hline Corporate Sustainability \\
\hline Sustainable Materials Processing \\
\hline Delivering Sustainable Change \\
\hline The Sustainable University \\
\hline $\begin{array}{l}\text { Role of Technology in } \\
\text { Sustainable Development }\end{array}$ \\
\hline Environmental Economics \\
\hline Industrial Ecology \\
\hline Globalisation \\
\hline $\begin{array}{l}\text { How societies fail; sustainable } \\
\text { development }\end{array}$ \\
\hline $\begin{array}{l}\text { Building Sustainable Societies } \\
\text { from Human Experience }\end{array}$ \\
\hline
\end{tabular}

Figure 1. The list on the left shows the sixteen face-to-face units (divided into four modules). Some of the material from these formed the basis of the five on-line units.

The video material for each unit lasts about an hour and is split into roughly 10 minute sections, based on evidence on the optimum duration for video (Bormann, 2014; Mason et al., 2013; Enfield, 2013). Each section has what we call a "reflec-tivity" ("e-tivity" in the standard literature, Salmon, 2013), which sets a topic for students to think about based on what they have just heard and as a potential discussion point for the forum. Prior to recording, the text and slides for on-line material were reviewed by one of our graduate interns in the University Environment Team. She suggested a number of points where clarification was needed for students coming to this material for the first time, and a number of instances where additional signposting would be helpful. These suggested changes were implemented.

For recognition for the HEAR a course must require ten hours of study time. This is rather limiting in the context of sustainable literacy. We reduced the assessment load by requiring students to study the introduction and any two other units and changing the written assessment accordingly. Students are presented with two very different views of the next 50 years and asked to write a short critique in the light of what they have learnt from the course. The course is approved for inclusion in the HEAR provided that students complete the introduction and the MCQs for two further units, and critique the essays to a satisfactory standard (50\% pass mark), leaving them free to follow the remaining units if they wish.

\section{OUTCOMES}

We turn here to the outcomes of the project focussing on the responses to our questionnaire (appendix). We used a questionnaire as an appropriate tool to gather basic information about the perceived quality of the presentation and therefore whether we would want to run it again in its current form. We also took the opportunity to ask about further study, as an indicator of possible interest. 
To advertise the course we enlisted the help of the Students' Union through publicity for a meeting to explain the course and answer questions, and through an article about the course in the Student Newspaper. Emails, with requests to forward information to staff and students, were sent to Departmental Administrators, ESD forum members and departmental environment coordinators. Almost all of the students replying to the evaluation questionnaire said they had heard about the course through the email from their departmental administrator. Even so, a number of students noted (either through the questionnaire or privately) that they had heard of the course only from other students and only after it was well underway (and therefore joined late or not at all).

A total of 250 staff and students signed up for the course; 86 completed enough multiple choice tests for a pass mark (50\%) and 49 students completed the essay assignment for HEAR recognition. This compares reasonably well with similar courses at other institutions for which we have data. The online course as a whole, including the recommended reading for all units, would correspond to approximately 75 hours of student work, from which it is clear that the HEAR requirements provide a rather minimal introduction to sustainability literacy. Interestingly the majority of the students seeking HEAR accreditation studied more than the minimum requirements and many included their own additional reading in their essay.

Students completing the course were asked to answer a questionnaire through BOS (Bristol Online Survey, see appendix). From this it emerged that the course had attracted students from a wide range of programmes, not just science disciplines (see question 1 in the Appendix). The comments from the 41 students who completed the survey were overwhelming positive. Sample comments taken from five different students were:

"As a new activity introduced by the university and campaigned for by the students union, it has certainly been a fantastic opportunity and a successful start. The course has a bright future amidst our modern world and the university should be really proud of that."

"Very good on-line course, I would like more science courses that are available for humanities students."

“I personally wasn't fond of the assessment -to write a review of 500ish words I felt was too restrictive and wasn't a good way for me to show how much reading and understanding I had gained."

"I do not feel that many people will use the forum to submit their own opinions and answers, as it is optional, therefore I feel that if it were obligatory to contribute to at least 3 or 4 then there would be a lot more replies."

"Although self-study was important, one session at least could be implemented to allow face to face interaction."

The video content was rated as good or very good by $35 / 40$ respondents and the presentation as good or very good by $36 / 40$. All but four of the students submitting the questionnaire were taking the course for HEAR accreditation. It is notable that for their choice of two out of four modules the most popular unit was "Are we Doomed?" perhaps because of the title. The least popular was the unit on energy and climate change. This is perhaps an aspect of sustainability with which students feel themselves already familiar.

Engagement with the forum was disappointing, most students either not contributing at all or doing no more than introducing themselves $(29 / 40)$. Attempts were made to encourage participation through contributions from the course convenor, but produced little engagement. Although most 
students (17/39) claimed that lack of time was the main barrier to engaging with the forum, we wondered if the totally asynchronous schedule for the course may have been a factor. Students started at a time of their choice and took any number of units in any order. For our second run of the course we suggested a standard schedule of fortnightly units with messages to students at the start of each unit. However, students are still able to complete the units at their own pace (and as a "binge" activity, studying units back-to-back). So, although those who wish to contribute to the forum have more of a framework in which to do so, participation has been no better than previously. Once this run of the course is complete, we will analyse the data to look at the extent to which scheduling has had any impact on the "binge" approach. Interestingly, the survey respondents were almost equally divided between those who studied the units over an extended period (» four weeks), those who studied it over about four weeks, and those who compressed their study into much less than four weeks.

Studies show that student-student interaction and student-staff interaction is an important factor in student engagement with on-line courses (Dixson, 2010). Had we achieved this, perhaps a greater number of students would have completed the course. However, our relatively high completion rates suggest that for this topic many students have a high degree of self-motivation.

\section{CONCLUSIONS}

The lessons learnt from the project fall into three groups: first concerning the production of the resources; second on the student responses; and finally on our impact on the University strategy.

To re-purpose the material for on-line presentation our initial intention was to record the face-toface workshops to generate discussion ideas for the on-line forum. It was also intended to use the recorded pre-session material as the basis for the on-line lectures. The recordings of the live workshops (in those limited cases where the sound was discernible) turned out not to be too useful, and discussion questions were therefore largely generated by the authors ab initio. The production standards of the pre-session powerpoint lectures for the campus course were considered to be of . insufficient quality and only a small amount of that material was in fact used. While this is not a problem for the campus course, where students regard the workshops as the main activity, for the on-line version, where the lectures are perceived as the central resource, and where students have certain expectations of production values from MOOCs, it was considered that the higher quality was essential.

The cost of setting up the course (in terms of staff time) therefore turned out to be much greater than anticipated. In addition, the maintenance of the course, involving setting up the web site, creating the advertising literature and interacting with students via email, constitute unfunded overheads. An attempt to populate the forum with discussion topics also took time. For the pilot these additional resources were provided either free or through the Centre for Interdisciplinary Science and the College of Medicine and Biological Sciences.

Much of the costs, including materials production and the web site, are start-up costs. For the recurrent costs, we have learnt how to make efficiencies (for example by requiring submission of work through our VLE rather than by email). But the continuation of the programme requires support for on-going activities such as registration of students, managing the forum and the marking of assignments. At present there is no formal mechanism of support for non-credit bearing courses.

We believe that the pilot has confirmed the demand for sustainability education and demonstrated that this can be satisfied at the University level through on-line learning. There is also the potential to expand the number of units in the on-line course based on further sustainability units from the Natural Sciences programme. A large majority of students completing the questionnaire expressed an interest in further study, $37 / 40$ in the form of further modules and $31 / 38$ in the manner of a "minor" programme. 
Subsequent developments have confirmed these suggestions. The course is running again in 2015-16 with 187 students signed up. The intention is to continue to run it in its present form, since it is highly rated by enough students to justify the costs. More importantly, the University has introduced a major/minor option into many degree programmes. This has been followed by approval for a minor in sustainability (led by the Department of Geography in cooperation with the Management Centre and the Centre for Interdisciplinary Science) of which Sustainable Futures will be part. For this, the on-line material will be re-developed with the help of our educational developers to provide a more interactive experience. Minor pathways constitute one quarter of the students' workload in each of their three years. Whether this is too great a commitment for most students remains to be seen, but it represents a major shift in the academic opportunity for students to engage with sustainability issues as part of their degree programmes at the University of Leicester. It is a substantial development, supported by senior management, and driven in part by the influence of this project.

\section{ACKNOWLEDGEMENTS}

We are grateful for the contributions from Yordan Nikolov (SU education) for help with publicity, Charlotte Bishop (Hungry for Change project) for draft content and to Sarah Roberts (graduate intern) for trialling the material. The project was supported in part by grants from the University of Leicester Teaching Enhancement Fund and from the HEA Biological Sciences Subject Centre.

\section{REFERENCES}

Bormann, J., 2014, Affordances Of Flipped Learning And Its Effects On Student Engagement And Achievement, University Of Northern lowa http://fln.schoolwires.net/cms/lib07/VA01923112/Centricity/Domain/41/bormann_lit_review.pdf

Dixson, M D, 2010, Creating effective student engagement in online courses: What do students find engaging? Journal of the Scholarship of Teaching and Learning, 10(2) pp. 1 - 13

Enfield J., 2013, Looking at the impact of the flipped classroom model of instruction on undergraduate multimedia students at CSUN Techtrends: Linking Research \& Practice To Improve Learning, 57(6),14-27. doi:10.1007/s11528-013-0698-1

- Holdsworth S and Thomas I, 2015, Framework for Introducing Education for Sustainable Development into University Curriculum, SAGE publications 9(2), 137-159, doi: $10.1177 / 0973408215588246$

Mason, G., Shuman, T., \& Cook, K., 2013, Comparing the effectiveness of an inverted classroom to a traditional classroom in an upper-division engineering course IEEE Transactions on Education, 56(4), 430-435. doi: 10.1109/TE.2013.2249066

Sterling S, Maxey, L and Luna H (Eds), The Sustainable University: Progress and prospects, Routledge Series in Sustainable Development, Routledge, 2013)

Salmon, G., 2013, E-tivities: The Key to Active Online Learning, 2nd edition (Routledge)

Tilbury D 2011, Higher Education for Sustainability: a global overview of commitment and progress in Global Universities, in Network for Innovation (GUNI) Higher Education's Commitment to sustainability: From Understanding to Action, World in Higher Education seies No 4 Barcelona GUNI)

UE4SD, 2015 Leading Practice Publications: Professional Development of university educators on Educations for Sustainable Development in European Countries. Editors Kapitulčinová D et al. Charles Univeristy in Progue, Prague, 
Williams D. P. and Parker K., 2012, Learn Chemistry: The Chemistry of Energy, (Royal Society of Chemistry) http://www.rsc.org/learn-chemistry 


\section{Appendix: Sustainable Futures Online}

Questionnaire

\begin{tabular}{|c|c|}
\hline $\begin{array}{l}\text { 1. If you are studying for a degree what is your degree } \\
\text { programme? }\end{array}$ & $\begin{array}{l}\text { 1: Staff Cert HE } \\
\text { 8: Masters; } \\
\text { 10: Geography; } \\
\text { 3: Geology, Psychology, Languages, Law; } \\
\text { 2: Biosciences, Media; } \\
\text { 1: American studies, Management, } \\
\text { Computer Science, Maths, Sociology, }\end{array}$ \\
\hline 2. What year are you in? & Yr1: 9, Yr2: 2, Yr3: 8, Yr4: 1 \\
\hline 3. Are you doing this for HEAR accreditation? & Yes 19 , No 1 \\
\hline 4. How did you find out about this course? & Email 34; Staff 4; Union 1; Student 1 \\
\hline $\begin{array}{l}\text { 5. Over what period of time did you complete this } \\
\text { course? (We are interested in whether you studied it } \\
\text { in a concentrated period or spread out over time.) }\end{array}$ & $\begin{array}{ll}\text { Extended (〉> 4 weeks): } & 11 \\
4 \text { weeks: } & 14 \\
\text { Compressed (<4 weeks): } 13\end{array}$ \\
\hline $\begin{array}{l}\text { 6. Is there any sustainability content in your degree } \\
\text { programme? }\end{array}$ & Yes 11 , No 29 \\
\hline $\begin{array}{l}\text { 6b If so about how much (approximate number of } \\
\text { credits so far) }\end{array}$ & $\begin{array}{l}\text { a little }(<10 \text { credits }): 11 \\
\text { some }(10-20 \text { credits): } 4 \\
\text { a lot }(>20) \text { credits: } \quad 1\end{array}$ \\
\hline \multicolumn{2}{|l|}{ 7. Would you be interested in } \\
\hline $\begin{array}{l}\text { (a) further opportunities to study modules in sustainability } \\
\text { and sustainable development? }\end{array}$ & Yes 37 , No 3 \\
\hline $\begin{array}{l}\text { (b) a "pathway" ( } 30 \text { credits per year) in sustainability } \\
\text { science and sustainable development. }\end{array}$ & Yes 31 , No 7 \\
\hline 8. Which units did you study: $00,01,02,03,04$ & $6,4,5,8,18^{4}$ \\
\hline \multicolumn{2}{|l|}{ 9. How would you rate the videos? } \\
\hline poor; fair; good; very good & $0,5,21,14$ \\
\hline Presentation: poor; fair; good; very good & $0,4,21,15$ \\
\hline Clarity of instructions? poor; fair; good; very good & $0,9,14,17$ \\
\hline Additional content? poor; fair; good; very good & $0,7,20,13$ \\
\hline $\begin{array}{l}\text { 10. Did you contribute to the on-line forums (other than } \\
\text { introducing yourself)? Yes/No }\end{array}$ & Yes 11 , No 29 \\
\hline \multicolumn{2}{|l|}{ If not, why not? } \\
\hline No-one else was writing anything & 6 \\
\hline Not useful & 3 \\
\hline Not enough time & 17 \\
\hline Other: & 3 \\
\hline $\begin{array}{l}\text { 11. Did you complete the MCQs for the units you studied? } \\
\text { Yes/No }\end{array}$ & Yes 40 , No 1 \\
\hline 12. Did you complete the essay assignment? Yes/No & Yes 38 , No 3 \\
\hline $\begin{array}{l}\text { 13. Any other comments: (We are particularly interested } \\
\text { in what you think worked well and how you think the } \\
\text { course might be improved). }\end{array}$ & $\begin{array}{l}\text { See main text for representative } \\
\text { examples }\end{array}$ \\
\hline
\end{tabular}

\footnotetext{
${ }^{4}$ This question appears to have been misinterpreted: since students were required to study Unit 00 (and two others) for the HEAR, the answers do not add up.
} 